\title{
Tear Film Proteome of Healthy Domestic Cats
}

\author{
Jéssica Fontes Veloso $\mathbb{D}^{1},{ }^{1}$ Paula Elisa Brandão Guedes $\mathbb{D},{ }^{2}$ Luciana Carvalho Lacerda $\mathbb{D},^{2}$ \\ Juliano Oliveira Santana $\left(\mathbb{D},{ }^{3}\right.$ Irma Yuliana Mora-Ocampo $(\mathbb{D})^{3}$ \\ Carlos Priminho Pirovani $(\mathbb{D}),{ }^{3}$ Arianne Pontes Oriá $(\mathbb{D}),{ }^{4}$ Alexandre Dias Munhoz $\left(\mathbb{D},{ }^{2}\right.$ \\ and Renata Santiago Alberto Carlos $\mathbb{D}^{2}$
}

${ }^{1}$ Multidisciplinary Campus of Barra, Federal University of Western Bahia, Av. 23 de Agosto, 873, Assunção, Barra, Bahia, Brazil
${ }^{2}$ Department of Agricultural and Environmental Sciences, Santa Cruz State University, Rodovia Jorge Amado, km 16, Salobrinho,
Ilhéus, Bahia, Brazil
${ }^{3}$ Department of Biological Sciences, Santa Cruz State University, Rodovia Jorge Amado, km 16, Salobrinho, Ilhéus, Bahia, Brazil
${ }^{4}$ Department of Pathology and Clinics, Federal University of Bahia, Av. Adhemar de Barros, 500, Ondina, Salvador, Bahia, Brazil

Correspondence should be addressed to Paula Elisa Brandão Guedes; paulaebg@gmail.com

Received 30 April 2021; Accepted 7 July 2021; Published 16 July 2021

Academic Editor: Remo Lobetti

Copyright (C) 2021 Jéssica Fontes Veloso et al. This is an open access article distributed under the Creative Commons Attribution License, which permits unrestricted use, distribution, and reproduction in any medium, provided the original work is properly cited.

\begin{abstract}
The aim of this study was to investigate the proteins found in tear film of healthy domestic cats. Schirmer tear test strips were used to collect tear samples of twelve healthy cats, which were mixed, centrifuged, and placed in a single $1.5 \mathrm{~mL}$ microtube that was frozen at $-20^{\circ} \mathrm{C}$, until analysis by two-dimensional polyacrylamide gel and mass spectrometry associated with high-performance liquid chromatography. The resulting spectra were analyzed and compared with the Swiss-Prot search tool. Forty peptides were detected in the analyzed protein fragments of 90 spots, with 16 proteins identified. Of these, the authors confirmed what has been already found in other studies: lactotransferrin, serum albumin, allergenic lipocalins, and neutrophil gelatinase-associated lipocalin. Others were considered novel in tear film samples of all species: cyclin-dependent protein kinase, serine/arginine repetitive matrix protein, apelin receptor, secretory protein related to C1q/TNF, Wee1, $\alpha-1,4$ glucan phosphorylase, and WD repeat domain 1 . The network was divided into 11 clusters, and a biological function was assigned. Most of the proteins have functions in the defense and maintenance of feline ocular surface homeostasis. Serum albumin is a bottleneck protein, with a high betweenness value. This paper is a pioneer in reporting, in-depth, the tear film proteome of domestic cats.
\end{abstract}

\section{Introduction}

Tear film (TF) is a complex and viscous trilaminar fluid composed mainly of proteins, lipids, electrolytes, and water [1], with a protective function for the ocular surface. This protection is based on the presence of proteins in the TF, which participate in the modulation of healing processes and in direct defense against pathogens [2].

Changes in the expression of tear proteins can be associated with systemic and ophthalmic diseases. Thus, its evaluation has been widely explored in human medicine as a noninvasive tool to discover molecular biomarkers for diagnosis and prognosis of several diseases $[3,4]$. For the evaluation of protein expression of TF, several techniques can be used, but mass spectrometry (MS) is currently the technique of choice to identify proteins in complex biological samples such as tears [5-8].

The description of tear microcomponents is important, especially of cats, a species whose proteomic data are not well analyzed in the literature. The study of microcomponents such as proteins and their properties can be the first step for future studies of disease biomarkers in this species $[1,9]$.

Indeed, when compared to human medicine, in the field of veterinary medicine, little research has been published involving the TF proteome, the exceptions being studies of canines [10-12]; rabbits [13]; koalas [14]; capuchin monkeys 
[15]; sheep, cows, and camels [9]; and horses, three species of birds, and six species of reptiles [11]. To the best of our knowledge, no studies have been published about cats.

It is thus relevant to investigate the domestic feline TF proteome since knowledge of the proteome profile in cats' tears is the first step toward future studies of possible disease biomarkers of feline ophthalmic diseases, as well as systemic diseases. Thus, the aim of this study was to describe the proteins found in the tear film of healthy domestic cats, which was possible to be obtained through the methodology used.

\section{Materials and Methods}

2.1. Ethical Considerations and Animals Included in the Study. This study was approved by the Ethics Committee on Animal Experimentation Use (CEUA) of the State University of Santa Cruz (UESC) (protocols 024/15 and 03/17). All procedures were conducted in accordance with the Association for Research in Vision and Ophthalmology's (ARVO) Statement for the Use of Animals in Ophthalmic and Vision Research and the NIH Statement and also followed the Cat-Friendly Practice guidelines. The animals were donated by the owners for research after formal consent. After the experiment, all the cats were adopted.

This study included 12 mixed-breed domestic cats (Felis catus), of both genders, between 11 and 12 months of age, living in a controlled environment. The selected cats were previously castrated, dewormed, and immunized against the main infectious diseases. They were also certified as healthy by physical examination, had complete blood count (CBC) performed, and the concentrations of alanine aminotransferase (ALT), aspartate aminotransferase (AST), gamma glutamyl transferase (GGT), bilirubins, urea, and creatinine were within normal range. The cats were also negative for Toxoplasma gondii, FIV/ FeLV, and feline coronavirus antibodies. In addition, a complete ophthalmic evaluation was performed, including the Schirmer tear test (STT) and intraocular pressure test, with results within the normal range, and the ocular surface was evaluated using fluorescein dyes and green lysamine (Ophthalmos, São Paulo, Brazil) and was considered healthy. All the ophthalmic tests were performed after proteomic sample collection to avoid any interference with the results.

2.2. Tear Film Collection. Tear film samples were collected in the morning hours, and when the tear wetted $30 \mathrm{~mm}$ on the Schirmer strips, the same ones used for STT-1, the strips were immediately placed in a $0.5 \mathrm{~mL}$ microtube (Protein LoBind Tubes; Eppendorf, São Paulo, Brazil) and placed in a thermal box until centrifugation. Immediately before centrifugation, the bottom of each microtube was punctured, and it was inserted into a larger $2.0 \mathrm{~mL}$ microcentrifuge tube (Protein LoBind Tubes; Eppendorf, São Paulo, Brazil) for extracting the tear fluid, as described by [16]. The TF was obtained through centrifugation $\left(25.830 \mathrm{~g}\right.$ for $10 \mathrm{~min}$ at $\left.4^{\circ} \mathrm{C}\right)$ of the Schirmer strips (Ophthalmos, São Paulo, Brazil) and placed in $1.5 \mathrm{~mL}$ microtubes.

As tear sample amount of each animal has low volume, it was necessary to mix the individual samples of the 12 cats, place in a single $1.5 \mathrm{~mL}$ microtube, and keep frozen at a temperature of $-20^{\circ} \mathrm{C}$, until protein preparation for twodimensional polyacrylamide gel (2D-SDS-PAGE).

2.3. TF Protein Quantification. The TF samples' protein was quantified by the Bradford method [17] with reading at 595 nm, using bovine serum albumin (BSA) as standard. Then, salt removal was performed to avoid influence on isoelectric focusing, thus making the sample purer. For this purpose, the total amount of $150 \mu \mathrm{L}$ of sample was mixed with $150 \mu \mathrm{L}$ of $20 \%$ TCA in plastic tubes, stored for 10 minutes on ice, and centrifuged for 5 minutes at 15,000 g. The supernatant was discarded, and the precipitate was washed twice with $200 \mu \mathrm{L}$ of $100 \%$ acetone, and once with $200 \mu \mathrm{L}$ of $80 \%$ acetone. For washes, centrifugation was done for $5 \mathrm{~min}$ at $18,000 \mathrm{~g}$. Subsequently, the supernatant was removed, the tubes were dried at room temperature, and the contents were subsequently resuspended in $200 \mu \mathrm{L}$ of rehydration buffer (urea at $7 \mathrm{~mol} \mathrm{~L}^{-1}$, thiourea at $2 \mathrm{~mol} \mathrm{~L}^{-1}, 2 \% \mathrm{CHAPS}$, and $0.002 \%$ bromophenol blue). Then, the proteins were quantified again with the 2D Quant Kit (GE Healthcare, Illinois, USA), according to the manufacturer's instructions.

\subsection{D Electrophoresis}

2.4.1. 1D SDS-PAGE. A volume of the sample containing $20 \mu \mathrm{g}$ of protein was mixed with a sample buffer $(5 \%$ $\beta$-mercaptoethanol; tris- $\mathrm{HCl}, 0.02 \mathrm{~mol} \mathrm{~L}^{-1} ; \mathrm{pH}, 6.8 ; 4 \%$ SDS; $27 \%$ glycerol; and $0.1 \%$ bromophenol blue). Then, the mixture solution and the low molecular weight marker (LMW) (14 to $97 \mathrm{kDa}$; GE Healthcare, Illinois, USA) were denatured separately at $95^{\circ} \mathrm{C}$ for $5 \mathrm{~min}$. After this, they were both applied on the top of the $12.5 \%$ polyacrylamide gel $(8 \times 10 \mathrm{~cm})$ in a vertical electrophoresis system (SE 260-Hoefer, San Francisco, California, USA), and LMW was inserted in the left column. The electrophoresis system was connected to a power supply in which the following running program was established: $150 \mathrm{~V}$ at $50 \mathrm{~mA}$ for 1.5 hours. After the run, the gel was placed in fixation buffer ( $40 \%$ alcohol and $10 \%$ acetic acid) for 1 hour, subsequently replaced by a Coomassie blue dye solution ( $8 \%$ sulfate ammonium, $0.8 \%$ phosphoric acid, $0.08 \%$ Coomassie Brilliant Blue G-250, and 20\% methanol) for 24 hours, under agitation. Finally, the gel was conditioned with distilled water under stirring for five days to remove excess dye. After all the mentioned processes, it was possible to observe the total protein band profiles in the gel.

2.4.2. $2 D$ SDS-PAGE. A mass of $150 \mu \mathrm{g}$ of protein, in a volume of $250 \mu \mathrm{L}$ of rehydration buffer containing dithiothreitol (DTT) and $1.25 \mu \mathrm{L}$ of ampholyte, was used for isoelectric focusing. This solution was deposited on the porcelain support (strip holder), and a $13 \mathrm{~cm}$ dehydrated gel strip was inserted above it, with an immobilized $\mathrm{pH}$ gradient of 3 to $10 \mathrm{NL}\left(\mathrm{pH} 3-10 \mathrm{NL}, 130 \times 3 \times 0.5 \mathrm{~mm}\right.$; Immobiline ${ }^{\mathrm{TM}}$ DryStrip, GE Healthcare, Illinois, USA), and $1 \mathrm{~mL}$ of DryStrip oil was added. The holder was then closed and inserted into the focuser. The protocol followed for 
isoelectrofocalization, in an Ettan IPGphor III system (GE Healthcare, Illinois, USA), was as follows: $12 \mathrm{~h}$ (overnight) at $20^{\circ} \mathrm{C}$ for hydration of the gel, $1 \mathrm{~h}$ at $500 \mathrm{Vh}, 1 \mathrm{~h}$ and $4 \mathrm{~min}$ at $1000 \mathrm{Vh}, 2 \mathrm{~h}$ and $30 \mathrm{~min}$ at $8000 \mathrm{Vh}$, and $22 \mathrm{~min}$ at $8000 \mathrm{Vh}$, in all cases at $20^{\circ} \mathrm{C}$ (focusing itself), totaling $17 \mathrm{~h}$ and $15 \mathrm{~min}$.

After isoelectric focusing, the gel strips were treated for $15 \mathrm{~min}$ with $7 \mathrm{~mL}$ of equilibration buffer (urea, $6 \mathrm{~mol} \mathrm{~L}^{-1} ; 2 \%$ SDS; $30 \%$ glycerol; tris- $\mathrm{HCl} 0.05 \mathrm{~mol} \mathrm{~L}^{-1}$; $\mathrm{pH} 8.8$ ) containing $0.21 \mathrm{~g}$ of $1 \% \mathrm{DTT}$, followed by an additional 15 minutes in $7 \mathrm{~mL}$ of equilibration buffer containing $175 \mathrm{~g}$ of $2.5 \%$ iodoacetamide. Finally, the strips were placed for 15 minutes in $7 \mathrm{~mL}$ of $1 \mathrm{x}$ running buffer (tris, $0.025 \mathrm{~mol} \mathrm{~L}^{-1}$; glycine, $0.19 \mathrm{~mol} \mathrm{~L}^{-1}$; SDS, $0.1 \%$; $\mathrm{pH}$, 8.3) [18]. In the three stages, the gel strips were kept under slow stirring. The already balanced strips were applied on top of the $12.5 \%$ polyacrylamide gel in a vertical electrophoresis system (SE 600 Ruby; GE Healthcare, Illinois, USA), and the LMW (14 to $97 \mathrm{kDa}$; GE Healthcare, Illinois, USA) was inserted on the left side on a piece of filter paper. Then, they were sealed with agarose $\left(25 \mathrm{mmol} \mathrm{L}^{-1}\right.$ of tris base, $192 \mathrm{mmol} \mathrm{L}^{-1}$ of glycine, $0.1 \%$ SDS, $0.5 \%$ agarose, and $0.002 \%$ bromophenol blue). The run was carried out with an electric current of $45 \mathrm{~mA}$ for $15 \mathrm{~min}$, $120 \mathrm{~mA}$ for $30 \mathrm{~min}$, and $150 \mathrm{~mA}$, in a BioRad Power Pac 3000 source. The temperature was maintained at approximately $11^{\circ} \mathrm{C}$ during the entire run. At this stage, each polypeptide chain migrated according to its $m / z$, and the run was stopped when bromophenol blue reached the end of the gel.

2.5. Image Analysis. After the runs, each of which lasted an average of 4 hours, the gel was placed for 1 hour in fixation buffer (40\% alcohol and 10\% acetic acid), subsequently replaced by a Coomassie blue dye solution $(8 \%$ ammonium sulfate, $0.8 \%$ phosphoric acid, $0.08 \%$ Coomassie Brilliant Blue G-250, and 20\% methanol), for six days, under agitation. Then, the gel was conditioned with distilled water under stirring for five days to remove excess dye. After washing, the gel was scanned, using the LabScanner program (Amersham Bioscience, New Jersey, USA), and analyzed for spot detection, using ImageMaster 2D Platinum 7.0 software (GE Healthcare, Illinois, USA). This analysis was carried out through the combination of automatic detection of the spots by software and manual detection.

2.6. Protein Identification by Mass Spectrometry. The fragments of the gel were cut, using a sterile scalpel, placed in separate identified microtubes, washed for 24 hours with $200 \mu \mathrm{L}$ of $25 \mathrm{mmol} \mathrm{L}^{-1} \mathrm{NH}_{4} \mathrm{HCO}_{3}$ in $50 \% \mathrm{ACN}(\mathrm{pH} 8)$ and vortexed for 10 minutes. Then, the fragments were washed with $200 \mu \mathrm{L}$ of Milli-Q water to remove the excess of the previous solution and were dehydrated in $100 \mu \mathrm{L}$ of $100 \%$ acetonitrile (ACN) for $10 \mathrm{~min}$ at room temperature. After this step, the supernatant was discarded, and the microtubes with the samples were dried in Concentrator 5301 (Eppendorf, São Paulo, Brazil) for approximately $10 \mathrm{~min}$ utes. Then, $5 \mu \mathrm{L}$ of cold trypsin gold solution $\left(25 \mathrm{ng} \mu \mathrm{L}^{-1}\right.$; Promega, Madison, USA) was added, and the microtubes were kept on ice for $10 \mathrm{~min}$, after which approximately $20 \mu \mathrm{L}$ of $\mathrm{NH}_{4} \mathrm{HCO}_{3}\left(25 \mathrm{mmol} \mathrm{L}^{-1}\right)$ was added. The trypsin- containing spots were incubated for 16 hours in an oven at $37^{\circ} \mathrm{C}$. Finally, the supernatant from the tubes was collected and transferred to new tubes, and the peptides were reextracted with $50 \mu \mathrm{L}$ of $50 \%$ acetonitrile containing $5 \%$ formic acid, under agitation, for $30 \mathrm{~min}$ in a Thermo Finemixer (SH2000-DX, Singapore). The volume of each sample was reduced in the Speed Vac until it reached approximately $10-15 \mu \mathrm{L}$.

The resulting peptides from tryptic digestion were subjected to liquid chromatography with tandem mass spectrometry (LC-MS/MS) in a nanoACQUITY system (Waters, Milford, USA) coupled to an ESI-Q-ToF micromass spectrometer (Waters, Milford, USA).

2.7. Interaction Network Analysis. An interaction network was built with proteins of the Mus musculus species homologous to the proteins identified in the proteomic analysis of the $\mathrm{TF}$ of cats since it is a model organism, and therefore, the network can give more information about protein interactions.

2.8. Statistical Analysis. The raw data were processed, and the resulting spectra were analyzed with the ProteinLynx Global SERVER 4.2 software (Waters, Milford, USA) and compared with the Swiss-Prot search (UniProtKB, https:// www.uniprot.org/), using the existing database 9685-Felis catus (Cat) (Felis silvestris catus).

For the interaction network analysis, the proteins were subjected to interactome analysis using the STRING database version 11.0 (http://string-db.org). They were analyzed individually with the following parameters: (i) meaning of network edges: confidence; (ii) active interaction sources: text mining, experiments, databases, coexpression, neighborhood, gene fusion, and co-occurrence; (iii) minimum required interaction score: high confidence (0.700); (iv) maximum number of interactors to show: 1st and 2nd shell is no more than 50 interactions. The file for each network was downloaded in TSV format, and later, the files were merged and analyzed with the Cytoscape software version 3.7.1. The modularity and centrality properties (betweenness and node degree) of the network were calculated using the igraph package of the statistical tool R. For each cluster, an enrichment analysis of gene ontology was performed using the BiNGO version 3.0.3 plugin.

\section{Results}

The tear electrophoretic protein profile of cats by SDS-PAGE showed bands with molecular masses distributed in the ranges between 14 and $97 \mathrm{kDa}$, with a well-defined band at around $79 \mathrm{kDa}$, which denotes lactotransferrin (LF).

After processing the images, 90 spots were detected, and 40 of these were identified by mass spectrometry (Figure 1). Of these, 16 different proteins (some homologs) were identified (Figure 2). Lactotransferrin was the most abundant protein, making up approximately $16 \%$ of the TF of healthy cats, followed by phosphoglycerate kinase with approximately $5 \%$. The protein data found in the study are described in Table 1. 


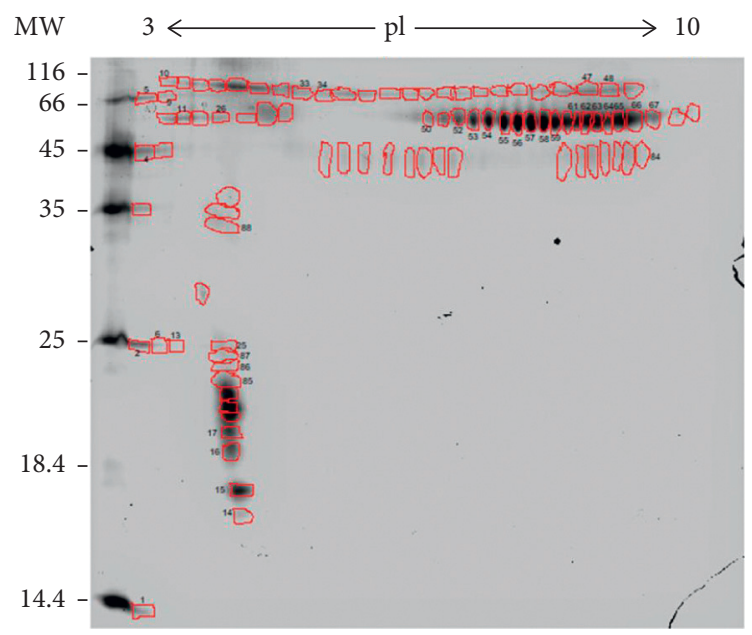

Figure 1: Two-dimensional polyacrylamide gel (2D-SDS-PAGE).

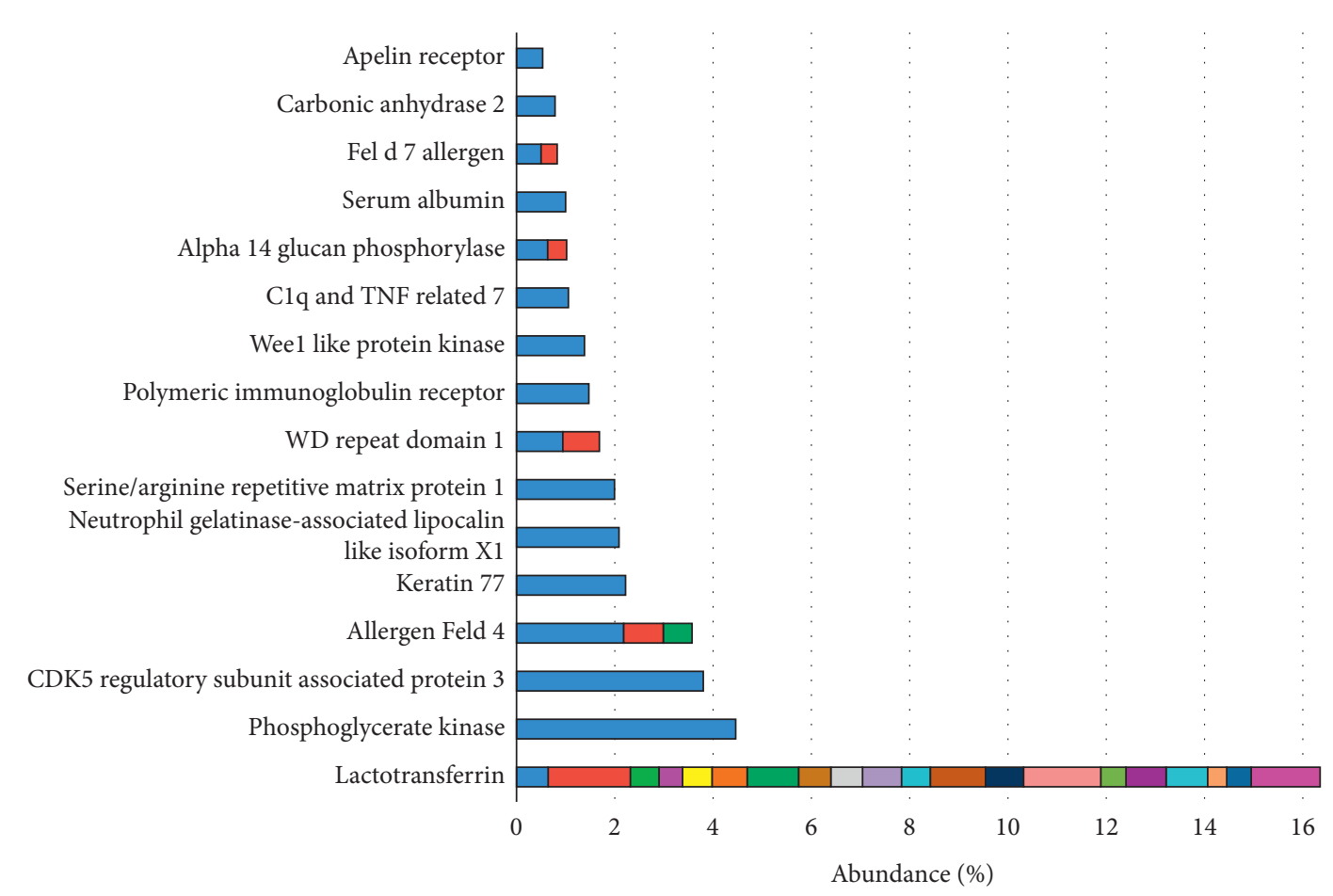

Figure 2: Graphical representation exposing the distribution of proteins and their abundances (\%), which can be considered a signature for the protein composition of tear film of healthy cats. The different colors in the abundance bars refer to the different spots where the same protein was identified, that is, for each protein, there is a bar with the sum of all the abundances found for itself.

The interaction network of proteins homologous to those identified in F. catus (Figure 3) is composed of 1,000 nodes (proteins), 16,149 edges, and 11 clusters. The network contains 118 proteins considered bottlenecks (betweenness value above average), of which eight are homologous to those identified in cats' TF (Table 2). The network also contains 416 proteins considered to be hubs (above average node degree value), of which six are homologous to the proteins identified in F. catus (Table 2), while three of the homologous proteins identified have both characteristics-bottleneck and hub-in the network. The homologous protein of $\mathrm{Clq}$ and TNF-related 7 (A0A2I2V388) had confidence parameters below those established for the construction of the network.

Cluster 2 had the highest number of proteins in the network, corresponding to the stimulus response (Figure 3). Within this cluster are the homologous of lactotransferrin (spots 11,33, 47, 48, 50, 52-59, and 61-67), serum albumin (spot 4), WD repeat domain 1 (spots 10 and 84), and neutrophil gelatinase-associated lipocalin (spot 85). 
TABle 1: Peptides identified in the tear of healthy cats.

\begin{tabular}{|c|c|c|c|c|c|c|c|}
\hline Spot & Protein & Access NCBI/UniProt & Gene & $\begin{array}{c}\text { Isoelectric } \\
\text { point }\end{array}$ & $\begin{array}{l}\text { Probability } \\
(\%)\end{array}$ & $\begin{array}{l}\text { Recognized } \\
\text { sequence }\end{array}$ & Molecular function \\
\hline 1 & Apelin receptor & M3X9N6_FELCA & APLNR & 7.7913 & 99.32 & 2 & $\begin{array}{l}\text { It modifies cellular } \\
\text { activity when it binds to } \\
\text { the apelin }[19,20]\end{array}$ \\
\hline 2 & Carbonic anhydrase 2 & M3W3J4_FELCA & CA2 & 7.0276 & 100 & 9 & $\begin{array}{l}\text { Reversible catalysis of } \\
\text { hydration of } \\
\text { bicarbonate and } \\
\text { dehydration of carbonic } \\
\text { acid }[21,22]\end{array}$ \\
\hline 4 & Serum albumin & A0A2I2U7Y0_FELCA & ALB & 5.1687 & 83.14 & 5 & $\begin{array}{l}\text { Antimicrobial defense } \\
\text { and healing }[23,24]\end{array}$ \\
\hline 5 & $\begin{array}{c}\alpha-1,4 \text { glucan } \\
\text { phosphorylase }\end{array}$ & A0A337SC59_FELCA & PYGM & 8.5646 & 62.24 & 33 & $\begin{array}{l}\text { It catalyzes the } \\
\text { formation of } \\
\text { glycoprotein [25] }\end{array}$ \\
\hline 6 & $\begin{array}{c}\text { Phosphoglycerate } \\
\text { kinase }\end{array}$ & A0A337SHN8_FELCA & PGK1 & 7.9065 & 79.49 & 5 & $\begin{array}{c}\text { Interaction with ATP } \\
{[26]}\end{array}$ \\
\hline 9 & $\begin{array}{c}\alpha-1,4 \text { glucan } \\
\text { phosphorylase }\end{array}$ & A0A337SC59_FELCA & PYGM & 8.5646 & 62.31 & 27 & $\begin{array}{l}\text { It catalyzes the } \\
\text { formation of } \\
\text { glycoprotein [25] }\end{array}$ \\
\hline 10 & WD repeat domain 1 & M3WEW2_FELCA & WDR1 & 6.1917 & 81.97 & 5 & Actin ligand $[27,28]$ \\
\hline 11 & Lactotransferrin & M3WKU0_FELCA & LTF & 7.6575 & 59.97 & 24 & $\begin{array}{l}\text { Binding protein, } \\
\text { multifunctional [29] }\end{array}$ \\
\hline 13 & $\begin{array}{c}\text { C1q and TNF-related } \\
7\end{array}$ & A0A2I2V388_FELCA & C1QTNF7 & 5.1962 & 85.26 & 2 & $\begin{array}{c}\text { Adiponectin paralogs } \\
{[30]}\end{array}$ \\
\hline 14 & Fel d 7 allergen & E5D2Z5_FELCA & LOC100533977 & 4.6666 & 94.62 & 15 & $\begin{array}{l}\text { Binding to small } \\
\text { hydrophobic molecules } \\
\text { and } \operatorname{IgE}[31,32]\end{array}$ \\
\hline 15 & Fel d 7 allergen & E5D2Z5_FELCA & LOC100533977 & 4.6666 & 80.18 & 15 & $\begin{array}{l}\text { Binding to small } \\
\text { hydrophobic molecules } \\
\text { and } \operatorname{IgE}[31,32]\end{array}$ \\
\hline 16 & Allergen Fel d 4 & ALL4_FELCA & Not described & 4.7216 & 99.99 & 7 & $\begin{array}{c}\text { Binding to small } \\
\text { hydrophobic molecules } \\
{[31,32]}\end{array}$ \\
\hline 17 & Allergen Fel d 4 & ALL4_FELCA & Not described & 4.7216 & 99.99 & 5 & $\begin{array}{l}\text { Binding to small } \\
\text { hydrophobic molecules } \\
\text { and } \operatorname{IgE}[31,32]\end{array}$ \\
\hline 25 & $\begin{array}{c}\text { CDK5 regulatory } \\
\text { subunit-associated } \\
\text { protein } 3\end{array}$ & A0A337SKT3_FELCA & CDK5RAP3 & 4.717 & 42.32 & 3 & $\begin{array}{l}\text { Binding to protein } \\
\text { kinase [33] }\end{array}$ \\
\hline 26 & $\begin{array}{l}\text { Polymeric } \\
\text { immunoglobulin } \\
\text { receptor }\end{array}$ & M3W5Z6_FELCA & PIGR & 5.4053 & 100 & 10 & $\begin{array}{l}\text { Binding to IgA and IgM } \\
{[34]}\end{array}$ \\
\hline 33 & Lactotransferrin & M3WKU0_FELCA & LTF & 7.6575 & 86.26 & 22 & $\begin{array}{l}\text { Multifunctional binding } \\
\text { protein [29] }\end{array}$ \\
\hline 34 & $\begin{array}{c}\text { Serine/arginine } \\
\text { repetitive matrix } \\
\text { protein } 1 \text { isoform X2 } \\
\text { (SRRM1) }\end{array}$ & XP_030879145.1 & TRY50791.1 & 9.9902 & 35.85 & 3 & $\begin{array}{c}\text { Participates in several } \\
\text { stages of mRNA } \\
\text { processing and } \\
\text { maturation, such as } \\
\text { splicing [35-37] }\end{array}$ \\
\hline 47 & Lactotransferrin & M3WKU0_FELCA & LTF & 7.6575 & 54.38 & 20 & $\begin{array}{c}\text { Multifunctional binding } \\
\text { protein [29] }\end{array}$ \\
\hline 48 & Lactotransferrin & M3WKU0_FELCA & LTF & 7.6575 & 50.57 & 21 & $\begin{array}{c}\text { Multifunctional binding } \\
\text { protein [29] }\end{array}$ \\
\hline 50 & Lactotransferrin & M3WKU0_FELCA & LTF & 7.6575 & 50.57 & 17 & $\begin{array}{c}\text { Multifunctional binding } \\
\text { protein [29] }\end{array}$ \\
\hline 52 & Lactotransferrin & A0A2I2V3V6_FELCA & LTF & 7.7844 & 50.22 & 29 & $\begin{array}{l}\text { Multifunctional binding } \\
\text { protein [29] }\end{array}$ \\
\hline 53 & Lactotransferrin & M3WKU0_FELCA & LTF & 7.6575 & 72.83 & 30 & $\begin{array}{l}\text { Multifunctional binding } \\
\text { protein [29] }\end{array}$ \\
\hline
\end{tabular}


TABLE 1: Continued.

\begin{tabular}{|c|c|c|c|c|c|c|c|}
\hline Spot & Protein & Access NCBI/UniProt & Gene & $\begin{array}{c}\text { Isoelectric } \\
\text { point }\end{array}$ & $\begin{array}{c}\text { Probability } \\
(\%)\end{array}$ & $\begin{array}{c}\text { Recognized } \\
\text { sequence }\end{array}$ & Molecular function \\
\hline 54 & Lactotransferrin & M3WKU0_FELCA & LTF & 7.6575 & 72.01 & 30 & $\begin{array}{l}\text { Multifunctional binding } \\
\text { protein [29] }\end{array}$ \\
\hline 55 & Lactotransferrin & M3WKU0_FELCA & LTF & 7.6575 & 100 & 44 & $\begin{array}{l}\text { Multifunctional binding } \\
\text { protein [29] }\end{array}$ \\
\hline 56 & Lactotransferrin & M3WKU0_FELCA & LTF & 7.6575 & 100 & 41 & $\begin{array}{l}\text { Multifunctional binding } \\
\text { protein [29] }\end{array}$ \\
\hline 57 & Lactotransferrin & M3WKU0_FELCA & LTF & 7.6575 & 100 & 37 & $\begin{array}{l}\text { Multifunctional binding } \\
\text { protein [29] }\end{array}$ \\
\hline 58 & Lactotransferrin & M3WKU0_FELCA & LTF & 7.6575 & 59.77 & 35 & $\begin{array}{l}\text { Multifunctional binding } \\
\text { protein [29] }\end{array}$ \\
\hline 59 & Lactotransferrin & M3WKU0_FELCA & LTF & 7.6575 & 81.42 & 33 & $\begin{array}{l}\text { Multifunctional binding } \\
\text { protein [29] }\end{array}$ \\
\hline 61 & Lactotransferrin & M3WKU0_FELCA & LTF & 7.6575 & 98.63 & 40 & $\begin{array}{l}\text { Multifunctional binding } \\
\text { protein [29] }\end{array}$ \\
\hline 62 & Lactotransferrin & M3WKU0_FELCA & LTF & 7.6575 & 100 & 36 & $\begin{array}{l}\text { Multifunctional binding } \\
\text { protein [29] }\end{array}$ \\
\hline 63 & Lactotransferrin & M3WKU0_FELCA & LTF & 7.6575 & 100 & 38 & $\begin{array}{l}\text { Multifunctional binding } \\
\text { protein [29] }\end{array}$ \\
\hline 64 & Lactotransferrin & M3WKU0_FELCA & LTF & 7.6575 & 100 & 40 & $\begin{array}{l}\text { Multifunctional binding } \\
\text { protein [29] }\end{array}$ \\
\hline 65 & Lactotransferrin & M3WKU0_FELCA & LTF & 7.6575 & 100 & 42 & $\begin{array}{l}\text { Multifunctional binding } \\
\text { protein [29] }\end{array}$ \\
\hline 66 & Lactotransferrin & M3WKU0_FELCA & LTF & 7.6575 & 100 & 45 & $\begin{array}{l}\text { Multifunctional binding } \\
\text { protein [29] }\end{array}$ \\
\hline 67 & Lactotransferrin & M3WKU0_FELCA & LTF & 7.6575 & 50.04 & 33 & $\begin{array}{l}\text { Multifunctional binding } \\
\text { protein [29] }\end{array}$ \\
\hline 84 & WD repeat domain 1 & M3WEW2_FELCA & WDR1 & 6.1917 & 91.53 & 5 & Actin ligand $[27,28]$ \\
\hline 85 & $\begin{array}{c}\text { Neutrophil } \\
\text { gelatinase-associated } \\
\text { lipocalin-like isoform } \\
\text { X1 (NGAL) }\end{array}$ & XP_003995976.1 & LOC101098498 & 5.0149 & 62.29 & 7 & $\begin{array}{c}\text { Binding and } \\
\text { transporting small } \\
\text { hydrophobic molecules } \\
\text { in addition to } \\
\text { participation in } \\
\text { immune responses, } \\
\text { signal transfunction, } \\
\text { and cell differentiation } \\
{[38-40]}\end{array}$ \\
\hline 86 & Allergen Fel d 4 & ALL4_FELCA & Not described & 4.7216 & 78.38 & 8 & $\begin{array}{l}\text { Binding to small } \\
\text { hydrophobic molecules } \\
\text { and } \operatorname{IgE}[31,32]\end{array}$ \\
\hline 87 & Keratin 77 & M3XG51_FELCA & KRT77 & 6.8177 & 100 & 4 & $\begin{array}{c}\text { Structural protein } \\
\text { present in epithelial cells } \\
{[41]}\end{array}$ \\
\hline 88 & $\begin{array}{l}\text { Wee1-like protein } \\
\text { kinase }\end{array}$ & M3X956_FELCA & WEE1 & 6.1725 & 67.81 & 3 & $\begin{array}{l}\text { Regulation of DNA } \\
\text { replication [42] }\end{array}$ \\
\hline
\end{tabular}

\section{Discussion}

The results of this study are pioneering in the identification of proteins present in the TF of healthy domestic cats. As already described by several researchers, knowledge of TF proteomics can assist in the investigation of ocular and systemic diseases $[3,4,10,11]$. Thus, the results obtained here are the first step toward further studies of domestic cats, to better elucidate the behavior of numerous ocular or systemic diseases as well as their diagnosis and prognosis.

TF has been intensively explored in proteomic studies due to its easy collection and handling. However, the final volume of tears obtained from each animal depends on individual regulation of tear flow compared to other body fluids [7]. Studies directed at the proteomic evaluation of TF are increasing, both in human and veterinary medicine. Furthermore, since proteins do not act alone, but are part of a large interaction network, a systematic biology analysis was performed to obtain a broader view of the processes that take place in the TF.

After collection and processing, the final pool volume was $150 \mu \mathrm{L}$. It was necessary to form pools to obtain an adequate final volume since $\mathrm{TF}$ is a type of sample that normally has small volume when compared to other samples, as reported in other studies $[11,13,15]$. Thus, analytical methods based on MS have been able to evaluate complex 


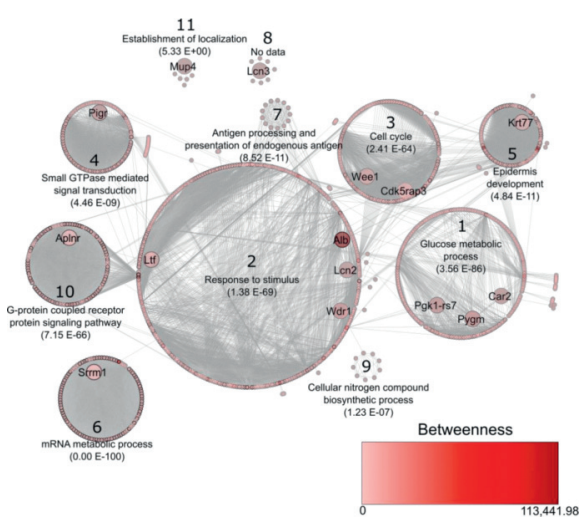

Figure 3: Interaction network of Mus musculus proteins homologous to those identified in Felis catus. Betweenness value represented by the color of the nodes, the lightest being the lowest value and the darkest being the highest value. It represents the ability of the node to join several clusters, or groups of nodes. Proteins with an elevated betweenness value have a high interaction with other proteins and are called bottleneck proteins. The width of the border of the nodes represents the value of node degree, so that the greater the width of the border, the greater the value and vice versa. The node degree property represents the number of connections that cross a single node, and the proteins with an above average node degree value are called hubs, which have an important regulatory function in the network. The clusters are subsets of nodes that are mostly connected to each other. In Figure 3, we have 11 clusters, each grouped in numbered circles. For each cluster, a biological process was assigned with the lowest corrected $p$ value, according to the BiNGO tool. Therefore, in this network figure, for each cluster, the biological function, the number of the cluster, and its $p$ value were indicated (the closer to zero, the more reliable). No annotation data were generated for cluster 8 (no data).

TABle 2: Mus musculus proteins homologous to the proteins identified in the tear film of cats (Felis catus).

\begin{tabular}{|c|c|c|c|c|c|c|}
\hline $\begin{array}{l}\text { Uniprot/NCBI ID } \\
(\text { F. catus })^{\mathrm{a}}\end{array}$ & Nome (Felis catus) $^{\mathrm{b}}$ & $\begin{array}{c}\text { Homóloga } \\
(\text { M. musculus })^{\mathrm{c}}\end{array}$ & $\begin{array}{l}\text { Identity } \\
(\%)^{\mathrm{d}}\end{array}$ & $\mathrm{BN}^{\mathrm{e}}$ & $\operatorname{Hub}^{\mathrm{f}}$ & Cluster $^{\mathrm{g}}$ \\
\hline E5D2Z5 & Fel d 7 allergen & $\operatorname{Lcn} 3$ & 39 & $\mathrm{~N}$ & $\mathrm{~N}$ & 8 \\
\hline ALL4 & Allergen Fel d 4 & Mup4 & 60 & $\mathrm{~N}$ & $\mathrm{~N}$ & 11 \\
\hline M3W5Z6 & Polymeric immunoglobulin receptor & Pigr & 64 & $\mathrm{Y}$ & $\mathrm{Y}$ & 4 \\
\hline XP_003995976.1 & $\begin{array}{c}\text { Neutrophil gelatinase-associated lipocalin-like } \\
\text { isoform X1 (NGAL) }\end{array}$ & $\operatorname{Lcn} 2$ & 65 & Y & $\mathrm{N}$ & 2 \\
\hline M3WKU0 & Lactotransferrin & Ltf & 67 & Y & Y & 2 \\
\hline A0A2I2U7Y0 & Serum albumin & Alb & 73 & $\mathrm{Y}$ & $\mathrm{Y}$ & 2 \\
\hline M3W3J4 & Carbonic anhydrase 2 & Car2 & 82 & $\mathrm{Y}$ & $\mathrm{N}$ & 1 \\
\hline A0A337SKT3 & CDK5 regulatory subunit-associated protein 3 & Cdk5rap3 & 85 & $\mathrm{~N}$ & $\mathrm{~N}$ & 3 \\
\hline M3X956 & Weel-like protein kinase & Wee1 & 86 & $\mathrm{~N}$ & $\mathrm{~N}$ & 3 \\
\hline A0A337SC59 & $\alpha-1,4$ glucan phosphorylase & Pygm & 87 & $\mathrm{Y}$ & $\mathrm{N}$ & 1 \\
\hline M3X9N6 & Apelin receptor & Aplnr & 88 & $\mathrm{~N}$ & $\mathrm{Y}$ & 10 \\
\hline A0A337SHN8 & Phosphoglycerate kinase & Pgk1-rs7 & 96 & $\mathrm{Y}$ & $\mathrm{N}$ & 1 \\
\hline XP_030879145.1 & $\begin{array}{l}\text { Serine/arginine repetitive matrix protein } 1 \text { isoform } \\
\qquad \text { X2 (SRRM1) }\end{array}$ & Srrm 1 & 99 & $\mathrm{~N}$ & Y & 6 \\
\hline M3XG51 & Keratin 77 & Krt77 & 99 & $\mathrm{~N}$ & $\mathrm{Y}$ & 5 \\
\hline M3WEW2 & WD repeat domain 1 & Wdr1 & 101 & $\mathrm{Y}$ & $\mathrm{N}$ & 2 \\
\hline
\end{tabular}

samples with small volume to map the protein profile of TF [14], as proven by our data.

Of the 16 proteins identified, the authors confirmed in cats what has been already found in other studies who described the presence of lactotransferrin [41], serum albumin $[11,23,43,44]$, two allergenic lipocalins $[45,46]$, neutrophil gelatinase-associated lipocalin (NGAL) [47], and keratin [41] in other TF studies. Three proteins (carbonic anhydrase II [22], polymeric immunoglobulin receptor $[48,49]$, and phosphoglycerate kinase [50]) have already been described in other structures of the lacrimal system. In addition, seven proteins (C1q/TNF-related secretory protein, three protein kinase family members, apelin receptor, $\alpha-1,4$ glucan phosphorylase, and WD repeat domain 1 ) to our knowledge have never been observed in any lacrimal system structure, so they are described here for the first time.

The great majority of proteins identified have a direct link with TF functions, whether in cell development and metabolism or in the performance of the innate immune defense of the lacrimal system, functions which have already been described in the literature regarding proteins present in TF $[13,23]$.

The proteins carbonic anhydrase II (spot 2), $\alpha-1,4$ glucan phosphorylase (spots 5 and 9), and phosphoglycerate kinase (spot 6) were identified. Their homologs belong to cluster 1 of the network (Figure 3), which corresponds to glucose metabolism. Carbonic anhydrase II has already been described in the lacrimal gland, the third eyelid gland, and the 
tarsal gland of dogs [22], but not in TF. The phosphoglycerate kinase is an important enzyme for protein biosynthesis [51], metabolic glycolysis [26], and, thus, for the metabolism of the lacrimal apparatus cells. The enzyme $\alpha-1,4$ glucan phosphorylase catalyzes the binding of carbohydrates to proteins and lipids, forming glycoproteins. This is important for cell adhesion and signaling, as well as for protein folding [25]. To the best of our knowledge, so far, no other study has identified this peptide in the TF of any animal species.

Lactotransferrin was the peptide identified in the largest number of spots in the TF of domestic cats (20 of the 40 spots) and with the highest abundance, corresponding to approximately $16 \%$ of the cats' TF in this study. This finding corroborates the literature, which cites the presence of the protein in question in the TF of humans [44], koalas [14], and dogs $[14,52]$. It is a multifunctional binding protein [29], produced by the acinar cells of the main and accessory lacrimal glands, with antimicrobial and anti-inflammatory action. Therefore, it plays an important role in innate immunity and helps maintain ocular surface homeostasis $[3,29]$. Its antimicrobial action occurs because lactotransferrin inhibits the classical complement activation pathway and binds to free iron in tears, reducing the availability of iron required for bacterial growth [3, 29, 43]. This is corroborated in the interaction network since homologs of this protein have strong interaction with proteins such as myeloperoxidase (score 0.755 ), which is microbicidal [53] and antileukoproteinase (score 0.969), a proteinase inhibitor that modulates the immune response after a bacterial infection [54]. This explains the fact that we found lactotransferrin with high abundance in cats' TF since the samples were from healthy animals.

Serum albumin is among the proteins frequently reported in humans $[23,43,44]$ and dogs' TF [11]. It has great importance in networks and, therefore, in cells and is considered a bottleneck protein with a high betweenness value, probably due to its ability to bind to various substrates such as water, $\mathrm{Ca}^{2+}, \mathrm{Na}+, \mathrm{K}+$, fatty acids, hormones, bilirubin, and drugs. In addition, it also can limit the use of iron and the growth of bacteria [55]. It is eliminated inside the tear from the conjunctival capillaries, exercising fundamental importance for the local antimicrobial defense [23] and acting as a marker of the absence of integrity of the blood-tear barrier $[43,56]$. It has a strong potential to be used as a biomarker of both ophthalmic and systemic diseases since it can derive from the leakage of plasma from conjunctival vessels, mixing with $\mathrm{TF}$ on the ocular surface $[23,56]$. A study carried out in dogs with corneal ulcers, uveitis, and glaucoma showed that the levels of tear albumin were up to 14.9 times higher in the injured eye compared to the healthy contralateral [56]. Therefore, albumin is a protein present in TF in healthy cats, and as happens in dogs, it is probably related to blood-tear barrier breakdown when present in high levels. Further studies of cats with ocular diseases must be performed to confirm this hypothesis.

NGAL, a glycoprotein member of the family of lipocalins, was also identified (spot 85), and like the allergenic lipocalins Fel d 4 and Fel d 7, it is a small extracellular protein
$[38,42]$ capable of binding and transporting small hydrophobic molecules. In addition, lipocalins participate in immune response regulation and signal transduction, enzymatic activities [40], and cell proliferation and differentiation [38]. In veterinary medicine, when the concentration of NGAL is high [57], it has also been described as a chronic kidney injury biomarker in dogs in serum and urine $[58,59]$, and in cats in plasma and urine [57]. Although tears contain proteins from the lipocalin family, NGAL has only been identified in human tears [47], so there is no information about it in cats' TF, suggesting the need for further studies to investigate its applicability as an early biomarker in TF for kidney injury in cats.

WD repeat domain 1 is a cytoplasmic protein encoded by the WDR1 gene [60]. This protein's known functions are signal transduction, RNA synthesis and processing, chromatin and cytoskeleton assembly, control of the cell cycle, and participation in cell apoptosis processes $[27,28,60]$. The homologs of this protein are found within the stimulus response cluster due to their interaction with the neuronal protein proto-oncogene tyrosine-protein kinase Src (score 0.759), which participates in signaling pathways that control a diverse spectrum of biological activities including gene transcription, immune response, cell adhesion, cell cycle progression, and apoptosis. Thus, the action of WD repeat domain 1 on the feline lacrimal system may be associated with the growth and structure of the cells that compose it. There are no reports in the literature of the presence of this protein in TF.

Homologs of cyclin-dependent protein kinase 5 (CDK5) associated with protein 3 (CDK5RAP3; spot 25) and Wee1like protein kinase (spot 88 ) are part of cluster 3, corresponding to the cell cycle. CDK5RAP3 is a unit regulator and linker of protein kinase, responsible for controlling the cell cycle from growth, differentiation to cell apoptosis [33] and can assist in the healing of corneal lesions, by stimulating the adhesion of corneal epithelial cells to one another when facing an injury [61]. In turn, Weel belongs to the serine/ threonine kinase family and is responsible for regulating the G2 phase of the cell cycle, preventing the mitosis of cells that have undergone mutation, thus preventing DNA replication [42]. Thus, we suggest that such proteins found in cats' TF participate in the control of the development, maturation, and proliferation of the cells of the corneal epithelial layer.

Still, in this context, serine/arginine repetitive matrix protein 1 (SRRM1) (spot 34) also belongs to the serinethreonine kinase family [62]. Its homolog belongs to cluster 6 , which represents the metabolic process of mRNA, since it is a protein encoded by the SRRM1 gene, hence also known by this acronym, and participates in several stages of mRNA processing and maturation, such as splicing [35-37]. Both CDK5RAP3 and SRRM1, reported in the TF of cats, have not yet been identified in any other species studied so far. In this regard, since the mRNA metabolism is essential for protein synthesis, this explains the presence of these components, active in the processing and maturation of the mRNA, in healthy cats' TF.

The polymeric immunoglobulin receptor (spot 26) and apelin receptor (spot 1 ) were identified. The homolog of the 
first one is part of cluster 4 , and the second one, of cluster 10 . Both correspond to processes related to signal transduction. The polymeric immunoglobulin receptor consists of a transmembrane domain receptor [48] that binds to IgA and IgM immunoglobulins [34], and IgA is abundantly present in TF. It is important for the innate mucosal immune response [63], and this has already been reported in other studies $[48,49]$, but not in TF samples of any animal species so far.

On the other hand, the apelin receptor (spot 1) is a peptide that activates and stimulates apelin function after binding. It is expressed in diverse cells and tissues, such as heart, blood vessels, and adipocytes $[19,20]$. Apelin belongs to the family of adipokines, which are part of a group of hormones and cytokines with proinflammatory action [64]. To our knowledge, this protein has not been described in TF of any species until now. Tracing an extension to its function in the ocular system, we suggest it is important for the formation of the vessels that nourish this organ, as well as possibly being present in the lipid component of TF.

The allergenic lipocalins Fel d 7 (spots 14 and 15) and Fel $d 4$ (spots 16, 17 and 86) are part of the family of lipocalins that are often reported in the TF of humans as proteins that bind to lipids and other proteins $[45,46]$. This specific class of allergenic lipocalins has only been previously described in dogs' TF, as one of the most abundant proteins [11]. Fel d 7 and Fel d 4 are found in body fluids and secretions, such as tears $[31,32,65]$. Thus, the study of these lipocalins can assist in the diagnosis of allergic reactions to cats.

Additionally, the protein related to $\mathrm{C} 1 \mathrm{q} / \mathrm{TNF}$ was also characterized, considered a secretory protein that belongs to the same family as adiponectin, both secreted by adipose tissue [30]. C1q/TNF 1 to 10 are part of this family, and although the metabolic functions of adiponectin are well characterized [66], the physiological processes regulated by $\mathrm{C} 1 \mathrm{q} / \mathrm{TNF}$ need to be better explored. It is known that C1q/ TNF 3 influences energy metabolism and insulin sensitivity [67] possibly secreted in the lipid layer of the TF.

Finally, keratin was also found on the TF of cats probably came from the epithelial and myoepithelial cells present in the lacrimal and meibomian glands, with the purpose of interacting with the TF lipid layer [68].

\section{Conclusions}

Most of the proteins identified have important functions in the defense and maintenance of homeostasis of the feline ocular surface. The relative abundance of all proteins found in this study promotes the first dispersion pattern, which can be considered a signature of the behavior and distribution of proteins in healthy cats.

The findings of the interaction network explain why lactotransferrin was present as the most abundant protein, because the samples were from healthy cats. The homologs of this protein showed high interaction with myeloperoxidase and antileukoproteinase, playing an important role in innate immunity and maintenance of ocular surface homeostasis. Serum albumin was equally identified, and the network demonstrated through the high betweenness value that this protein behaves as a bottleneck protein in cats' TF, probably due to its ability to bind to various substrates.

Seven proteins are described here for the first time in TF, cyclin-dependent protein kinase, serine/arginine repetitive matrix protein, apelin receptor, secretory protein related to C1q/TNF, Wee1, $\alpha-1,4$ glucan phosphorylase, and WD repeat domain 1. Currently, there are more advanced techniques for proteomic analysis of biological samples, which can generate more accurate and complete results regarding the protein composition of the tear film, but at the moment, this equipment was the one available to our team. Despite this, this study brings the first description of proteins in cats' TF and is the first step towards future studies about biomarkers of feline ophthalmic and systemic diseases. Thus, from this study, we obtained a first step of knowledge of the main proteins present in the tear film of healthy domestic cats and must stimulate new studies covering a larger number of samples and employing more advanced techniques.

\section{Data Availability}

The data used to support the findings of this study are included within the article.

\section{Conflicts of Interest}

The authors declare that there are no conflicts of interest regarding the publication of this paper.

\section{Acknowledgments}

The authors would like to thank UESC for offering development conditions for this study, such as availability of laboratories and equipment, and to the Bahia State Research Support Foundation (FAPESB) for providing grants. This study was financed by Santa Cruz State University (UESC), through the provision of physical space for the development of research and scholarships to undergraduate students and in part by the Coordenação de Aperfeiçoamento de Pessoal de Nível Superior-Brasil (CAPES) (finance code: 001), through research grants to Graduate Scholarships Postgraduate Students.

\section{References}

[1] L. Zhou and R. W. Beuerman, "Tear analysis in ocular surface diseases," Progress in Retinal and Eye Research, vol. 31, no. 6, pp. 527-550, 2012.

[2] G. A. Georgiev, P. Eftimov, and N. Yokoi, "Structure-function relationship of tear film lipid layer: a contemporary perspective," Experimental Eye Research, vol. 163, pp. 17-28, 2017.

[3] H. G. Hanstock, J. P. Edwards, and N. P. Walsh, "Tear lactoferrin and lysozyme as clinically relevant biomarkers of mucosal immune competence," Frontiers in Immunology, vol. 10, pp. 1178-1211, 2019.

[4] G. A. De Souza, L. M. F. Godoy, and M. Mann, "Identification of 491 proteins in the tear fluid proteome reveals a large 
number of proteases and protease inhibitors," Genome Biology, vol. 7, pp. 1-11, 2006.

[5] S. Hagan, E. Martin, and A. Enríquez-de-Salamanca, "Tear fluid biomarkers in ocular and systemic disease: potential use for predictive, preventive and personalised medicine," The EPMA Journal, vol. 7, pp. 15-20, 2016.

[6] J. Soria, A. Acera, J. Merayo-Lloves et al., "Tear proteome analysis in ocular surface diseases using label-free LC-MS/MS and multiplexed-microarray biomarker validation," Scientific Reports, vol. 7, p. 17478, 2017.

[7] M. Winiarczyk, D. Winiarczyk, T. Banach et al., "Dog tear film proteome in-depth analysis," PLoS One, vol. 10, pp. e0144242-e0144315, 2015.

[8] L. Zhou, S. Z. Zhao, S. K. Koh et al., "In-depth analysis of the human tear proteome," Journal of Proteomics, vol. 75, no. 13, pp. 3877-3885, 2012.

[9] F. A. Shamsi, Z. Chen, J. Liang et al., "Analysis and comparison of proteomic profiles of tear fluid from human, cow, sheep, and camel eyes," Investigative Opthalmology \& Visual Science, vol. 52, no. 12, pp. 9156-9165, 2011.

[10] S. Couture, M. Doucet, M. Moreau, and M. Carrier, “Topical effect of various agents on gelatinase activity in the tear film of normal dogs," Veterinary Ophthalmology, vol. 9, no. 3, pp. 157-164, 2006.

[11] A. C. Raposo, R. D. Portela, M. Aldrovani, T. D. Barral, D. Cury, and A. P Oriá, "Comparative analysis of tear composition in humans, domestic mammals, reptiles, and birds," Frontiers in Veterinary Science, vol. 7, pp. 283-312, 2020.

[12] D. Winiarczyk, M. Winiarczyk, S. Winiarczyk, L. Adaszek, and K. Michalak, "Proteomic analysis of tear film composition in diabetic dogs," Acta Ophthalmologica, vol. 99, 2021.

[13] L. Zhou, R. W. Beuerman, A. Barathi, and D. Tan, "Analysis of rabbit tear proteins by high-pressure liquid chromatography/ electrospray ionization mass spectrometry," Rapid Communications in Mass Spectrometry, vol. 17, no. 5, pp. 401-412, 2003.

[14] S. Hemsley, N. Cole, P. Canfield, and M. D. P. Willcox, "Protein microanalysis of animal tears," Research in Veterinary Science, vol. 68, no. 3, pp. 207-209, 2000.

[15] A. C. Raposo, R. D. Portela, A. Masmali et al., "Evaluation of lacrimal production, osmolarity, crystallization, proteomic profile, and biochemistry of capuchin monkeys' tear film," Journal of Medical Primatology, vol. 47, no. 6, pp. 371-378, 2018.

[16] A. P. Oriá, A. C. S. Raposo, N. L. L. C. Araújo, F. B. Lima, and A. M. Masmali, "Tear ferning test in healthy dogs," Veterinary Ophthalmology, vol. 21, no. 4, pp. 391-398, 2018.

[17] M. M. Bradford, "A rapid and sensitive method for the quantitation of microgram quantities of protein utilizing the principle of protein-dye binding," Analytical Biochemistry, vol. 72, no. 1-2, pp. 248-254, 1976.

[18] G. S. Monteiro Reis, A.-A. Furtado de Almeida, N. de Almeida Santos et al., "Proteomic profiles of young and mature cocoa leaves subjected to mechanical stress caused by wind," Plant Physiology and Biochemistry, vol. 155, pp. 851867, 2020.

[19] S. Esmaeili, F. Bandarian, B. Esmaeili, and E. Nasli-Esfahani, "Apelin and stem cells: the role played in the cardiovascular system and energy metabolism," Cell Biology International, vol. 43, no. 12, pp. 1332-1345, 2019.

[20] K. Mehri, S. M. Banan Khojasteh, B. K Seyed Mahdi et al., "Effect of troxerutin on apelin-13, apelin receptors (APJ), and ovarian histological changes in the offspring of high-fat diet fed rats," Iranian Journal of Basic Medical Sciences, vol. 22, pp. 637-642, 2019.

[21] R. E. Tashian, "Genetics of the mammalian carbonic anhydrases," Advances in Genetics, vol. 30, pp. 321-356, 1992.

[22] Y. Sugiura, S. Soeta, N. Ichihara et al., "Immunohistolocalization and gene expression of the carbonic anhydrase isoenzymes (CA-II and CA-VI) in glands associated with the canine lacrimal apparatus," Anatomia, Histologia, Embryologia, vol. 39, no. 1, pp. 1-6, 2010.

[23] G. Runström, A. Mann, and B. Tighe, "The fall and rise of tear albumin levels: a multifactorial phenomenon," The Ocular Surface, vol. 11, no. 3, pp. 165-180, 2013.

[24] L. Sebbag, E. M. McDowell, P. M. Hepner, and J. P. Mochel, "Effect of tear collection on lacrimal total protein content in dogs and cats: a comparison between Schirmer strips and ophthalmic sponges," BMC Veterinary Research, vol. 14, no. 1, pp. 61-68, 2018.

[25] Z. Ubiparip, K. Beerens, J. Franceus, R Vercauteren, and $\mathrm{T}$ Desmet, "Thermostable alpha-glucan phosphorylases: characteristics and industrial applications," Applied Microbiology and Biotechnology, vol. 102, pp. 8187-8202, 2018.

[26] Z. Chen, W. Zhuang, Z. Wang et al., "MicroRNA-450b-3p inhibits cell growth by targeting phosphoglycerate kinase 1 in hepatocellular carcinoma," Journal of Cellular Biochemistry, vol. 120, no. 11, pp. 18805-18815, 2019.

[27] E. J. Neer, C. J. Schmidt, R. Nambudripad, and T. F. Smith, "The ancient regulatory-protein family of WD-repeat proteins," Nature, vol. 371, no. 6495, pp. 297-300, 1994.

[28] T. F. Smith, C. Gaitatzes, K. Saxena, and E. J. Neer, "The WD repeat: a common architecture for diverse functions," Trends in Biochemical Sciences, vol. 24, no. 5, pp. 181-185, 1999.

[29] A. Y. Alhalwani, R. L. Davey, N. Kaul et al., "Modification of lactoferrin by peroxynitrite reduces its antibacterial activity and changes protein structure," Proteins, vol. 88, pp. 1-9, 2019.

[30] P. E. Scherer, "Adipose tissue: from lipid storage compartment to endocrine organ," Diabetes, vol. 55, no. 6, pp. 1537-1545, 2006.

[31] D. Apostolovic, S. Sánchez-Vidaurre, K. Waden et al., "The cat lipocalin Fel d 7 and its cross-reactivity with the dog lipocalin Can f 1," Allergy, vol. 71, no. 10, pp. 1490-1495, 2016.

[32] B. Bonnet, K. Messaoudi, F. Jacomet et al., "An update on molecular cat allergens: Fel d 1 and what else? Chapter 1: Fel d 1, the major cat allergen," Allergy, Asthma Clin Immunol, vol. 14, pp. 1-9, 2018.

[33] E. A. Nigg, "Cyclin-dependent protein kinases: key regulators of the eukaryotic cell cycle," BioEssays, vol. 17, no. 6, pp. 471-480, 1995 .

[34] C. S. Kaetzel, "The polymeric immunoglobulin receptor: bridging innate and adaptive immune responses at mucosal surfaces," Immunological Reviews, vol. 206, no. 1, pp. 83-99, 2005.

[35] B. J. Blencowe, R. Issner, J. A. Nickerson, and P. A. Sharp, "A coactivator of pre-mRNA splicing," Genes \& Development, vol. 12, no. 7, pp. 996-1009, 1998.

[36] S. McCracken, D. Longman, I. L. Johnstone, J. F. Cáceres, and B. J. Blencowe, "An evolutionarily conserved role for SRm160 in $3^{\prime}$-end processing that functions independently of exon junction complex formation," Journal of Biological Chemistry, vol. 278, no. 45, pp. 44153-44160, 2003.

[37] K. Chwalenia, F. Qin, S. Singh, and H. Li, "A cell-based splicing reporter system to identify regulators of cis-splicing between adjacent genes," Nucleic Acids Research, vol. 47, pp. e24-10, 2019. 
[38] T. Bratt, "Lipocalins and cancer," Biochimica et Biophysica Acta (BBA)-Protein Structure and Molecular Enzymology, vol. 1482, no. 1-2, pp. 318-326, 2000.

[39] D. R. Flower, A. C. T. North, and C. E. Sansom, "The lipocalin protein family: structural and sequence overview," Biochimica et Biophysica Acta (BBA)-Protein Structure and Molecular Enzymology, vol. 1482, no. 1-2, pp. 9-24, 2000.

[40] J. Grzyb, D. Latowski, and K. Strzałka, "Lipocalins-a family portrait," Journal of Plant Physiology, vol. 163, no. 9, pp. 895-915, 2006.

[41] S. A. Balasubramanian, V. C. Wasinger, D. C. Pye, and M. D Willcox, "Preliminary identification of differentially expressed tear proteins in keratoconus," Molecular Vision, vol. 19, pp. 2124-2134, 2013.

[42] T. G. Cross, D. Scheel-Toellner, N. V. Henriquez, E. Deacon, M. Salmon, and J. M. Lord, "Serine/threonine protein kinases and apoptosis," Experimental Cell Research, vol. 256, no. 1, pp. 34-41, 2000.

[43] S. A. Balasubramanian, D. C. Pye, and M. D. P. Willcox, "Levels of lactoferrin, secretory IgA and serum albumin in the tear film of people with keratoconus," Experimental Eye Research, vol. 96, pp. 132-137, 2001.

[44] M. Dor, S. Eperon, P. H. Lalive et al., "Investigation of the global protein content from healthy human tears," Experimental Eye Research, vol. 179, pp. 64-74, 2018.

[45] D. A. Dartt, "Tear Lipocalin: structure and function," The Ocular Surface, vol. 9, no. 3, pp. 126-138, 2011.

[46] M. D. Willcox, "Tear film, contact lenses and tear biomarkers," Clinical and Experimental Optometry, vol. 102, no. 4, pp. 350-363, 2019.

[47] A. R. Pradeep, K. Nagpal, S. Karvekar et al., "Levels of lipocalin-2 in crevicular fluid and tear fluid in chronic periodontitis and obesity subjects," Journal of Investigative and Clinical Dentistry, vol. 7, pp. 376-382, 2015.

[48] E. Evans, W. Zhang, G Jerdeva et al., "Direct interaction between Rab3D and the polymeric immunoglobulin receptor and trafficking through regulated secretory vesicles in lacrimal gland acinar cells," American Journal of Physiology. Cell Physiology, vol. 294, pp. C662-C674, 2008.

[49] E. Hayakawa, B. Landuyt, G. Baggerman et al., "Peptidomic analysis of human reflex tear fluid," Peptides, vol. 42, pp. 63-69, 2013.

[50] R. Joseph, O. P. Srivastava, and R. R. Pfister, "Differential epithelial and stromal protein profiles in keratoconus and normal human corneas," Experimental Eye Research, vol. 92, no. 4, pp. 282-298, 2011.

[51] A. N. Sasikumar, W. B. Perez, and T. G. Kinzy, "The many roles of the eukaryotic elongation factor 1 complex," Wiley Interdisciplinary Reviews: RNA, Wiley Interdiscip Rev RNA, vol. 3, no. 4, pp. 543-555, 2012.

[52] C. de Freitas Campos, N. Cole, D. V. Dyk et al., "Proteomic analysis of dog tears for potential cancer markers," Research in Veterinary Science, vol. 85, no. 2, pp. 349-352, 2008.

[53] Y. Aratani, "Myeloperoxidase: its role for host defense, inflammation, and neutrophil function," Archives of Biochemistry and Biophysics, vol. 640, pp. 47-52, 2018.

[54] J. Vandooren, P. Goeminne, L. Boon et al., "Neutrophils and activated macrophages control mucosal immunity by proteolytic cleavage of antileukoproteinase," Frontiers in Immunology, vol. 9, pp. 1154-1212, 2018.

[55] S. A. Yadav, D. P. Yeggoni, E. Devadasu, and R. Subramanyam, "Molecular binding mechanism of 5-hydroxy-1-methylpiperidin-2-one with human serum albumin,"
Journal of Biomolecular Structure and Dynamics, vol. 36, no. 3, pp. 810-817, 2018.

[56] L. Sebbag, R. A. Albaugh, A. Weaver et al., "Histamine-induced conjunctivitis and breakdown of blood-tear barrier in dogs: a model for ocular pharmacology and therapeutics," Frontiers in Pharmacology, vol. 10, pp. 1-11, 2019.

[57] I.-C. Wang, W.-L. Hsu, P.-H. Wu, H.-Y. Yin, H.-J. Tsai, and Y.-J. Lee, "Neutrophil gelatinase-associated lipocalin in cats with naturally occurring chronic kidney disease," Journal of Veterinary Internal Medicine, vol. 31, no. 1, pp. 102-108, 2017.

[58] G. Segev, C. Palm, B. LeRoy, L. D. Cowgill, and J. L. Westropp, "Evaluation of neutrophil gelatinase-associated lipocalin as a marker of kidney injury in dogs," Journal of Veterinary Internal Medicine, vol. 27, no. 6, pp. 1362-1367, 2013.

[59] W.-L. Hsu, Y.-S. Lin, Y.-Y. Hu, M.-L. Wong, F.-Y. Lin, and Y.-J. Lee, "Neutrophil gelatinase-associated lipocalin in dogs with naturally occurring renal diseases," Journal of Veterinary Internal Medicine, vol. 28, no. 2, pp. 437-442, 2014.

[60] D. Li and R. Roberts, "Human Genome and Diseases: WDrepeat proteins: structure characteristics, biological function, and their involvement in human diseases," Cellular and Molecular Life Sciences, vol. 58, no. 14, pp. 2085-2097, 2001.

[61] C. Y. Gao, M. A. Stepp, R. Fariss, and P. Zelenka, "Cdk5 regulates activation and localization of Src during corneal epithelial wound closure," Journal of Cell Science, vol. 117, no. 18, pp. 4089-4098, 2004.

[62] A. Lapolla, S. Porcu, M. Roverso et al., "A preliminary investigation on placenta protein profile reveals only modest changes in well controlled gestational diabetes mellitus," European Journal of Mass Spectrometry, vol. 19, no. 3, pp. 211-223, 2013.

[63] G. J. Niu, S. Wang, J. D. Xu et al., "The polymeric immunoglobulin receptor-like protein from Marsupenaeus japonicus is a receptor for White spot syndrome virus infection," PLoS Pathogens, vol. 15, pp. e1007558-e1007628, 2019.

[64] W. E. Stansfield, M. Ranek, A. Pendse et al., "The pathophysiology of cardiac hypertrophy and heart failure," in Cellular and Molecular Pathobiology of Cardiovascular Disease, M. S. Willis, J. W. Homeister, and J. R. Stone, Eds., pp. 51-78, Elsevier, San Diego, CA, USA, 1st edition, 2014.

[65] W. Smith, A. J. L. Butler, L. A. Hazell et al., "Fel d 4, a cat lipocalin allergen," Clinical Experimental Allergy, vol. 34, no. 11, pp. 1732-1738, 2004.

[66] T. Kadowaki, T. Yamauchi, N. Kubota et al., "Adiponectin and adiponectin receptors in insulin resistance, diabetes, and the metabolic syndrome," Journal of Clinical Investigation, vol. 116, no. 7, pp. 1784-1792, 2006.

[67] M. Kon, Y. Ebi, and K. Nakagaki, "Effects of a single bout of high-intensity interval exercise on C1q/TNF-related proteins," Applied Physiology, Nutrition, and Metabolism, vol. 44, no. 1, pp. 47-51, 2019.

[68] C. K. Palaniappan, B. S. Schütt, L. Bräuer, M. Schicht, and T. J. Millar, "Effects of keratin and lung surfactant proteins on the surface activity of meibomian lipids," Investigative Opthalmology \& Visual Science, vol. 54, no. 4, pp. 2571-2581, 2013. 